\title{
Restructuring of Ceramics Features with Changes in the Large and \\ Nanocrystalline Ceramic System Ratio
}

MIHAIL GRIGORIEV - Tomsk State University (TSU), Tomsk (Russia) • grv@ispms.tsc.ru

LÁszLó A. GÖMZE - University of Miskolc, Egyetemváros, Miskolc (Hungary) •

IGREX Engineering Service Ltd, Igrici (Hungary) - femgomze@uni-miskolc.hu • igrex2009@yandex.ru

SERGEY N. KULKOV - Tomsk State University (TSU), Tomsk (Russia) • Institute of Strength Physics and Materials Science SB RAS, Tomsk (Russia) • grv@ispms.tsc.ru • kulkov@ms.tsc.ru

Received: 28. 06. 2014. - Érkezett: 2014. 06. 28. - http://dx.doi.org/10.14382/epitoanyag-jsbcm.2014.10

\section{Abstract}

The structure and properties of ceramic based on alumina powders systems produced by the method of thermal decomposition of hydroxide aluminum and the plasma-spray pyrolysis method has been studied. It is shown that at the maintenance of $60 \%$ plasma-chemical powder $\mathrm{Al}_{2} \mathrm{O}_{3}$ in mix sharp change strength characteristics which those more than have less porosity is observed. Approximation of strength dependence vs. average pore size to porousless state shows a possibility of obtaining material with almost theoretical strength. Correlation between microstresses in crystallites and macrostrength in sintered ceramics was found.

Keywords: alumina, ceramic powders, microstructure, nanocrystalline, plasma-spray, pyrolysis, strength, stress

\section{Introduction}

Using nano-sized ceramic powders which are not in equilibrium opens up entirely new opportunities to obtain highly porous ceramics [1-5]. Due to the developed surface of the nanocrystalline particles, special nanocrystalline structures are formed with a high bonding strength at the grain boundaries, providing high strength for the ceramics [6-8].

A promising method for creating permeable ceramic materials with high porosity is the mixing large-fractured and ultrafine powders [9], and the geometry of the pores obtained in such a way is determined by the size and shape of largefractured powder particles [10]. However, when creating a porous ceramic material in this manner ultra-fine powder is used only as an additive (as a rule up to $10 \%$ ) [11], in other words, the pattern formation in ceramics porous structures with ultrafine powders, over a wide range of content, are not well understood. However, the data on the pore structure of those materials and its relation to the fine crystal structure parameters have a fundamental importance in the analysis of the deformation behavior $[12,13]$.

The aim of this paper is to investigate the crystal structure of the thin porous alumina ceramics synthesized from powders with different particle sizes (dispersion).

\section{Materials and methods}

To obtain porous ceramic mixture powders, mixtures of powder were prepared in a wide range from technical alumina (GOST 30558-98) to plasma chemical $\mathrm{Al}_{2} \mathrm{O}_{3}$ (TU -2320-00107622928-96). Sintering is performed at temperatures of $1200,1300,1400,1500,1600$ and $1650^{\circ} \mathrm{C}$ for duration in the isothermal hold of one hour.

X-ray diffraction analysis was performed on ceramics (DRON UM1) with filtered CuKa radiation. The average
Mihail V. Grigoriev, PhD has finished the Polytechnical Institute of the Siberian Federal University in 2007. At present time he is a post-doctoral fellow in Institute of Strength Physics and Materials Science of Siberian Branch of the Russian Academy of Science under guidance Prof. Kulkov. Topic of his PhD. work was „Features of deformation and fracture of porous alumina ceramics based on nanopowders".

Prof. Sergey N. Kulkov Prof. Kulkov is head of Department of Ceramics in the Institute of Strength Physics and Materials Science of the Russian Academy of Science since 1989. He has got scientific degrees "Doctor of Physics and Mathematical Sciences" in 1990. Since 1992 he's working as professor both in Tomsk State University and in Tomsk Polytechnic University. In 1997 he had a

Soros Professor grant. His research works are represented in 5 books, more than 150 articles, 18 patents and many International Symposiums and Conferences. At present he is head of department "Theory of Strength and Mechanic of Solids", member of "The American Ceramic Society" of "The APMI - International" and the DYM AT Society (France),

Prof. László A. Gömze Establisher (in July 1st, 1999) and head of Department of Ceramics and Silicate Engineering in the University of Miskolc, Hungary. Since then 7 students from the department have successfully completed their PhD theses and 4 of them were managed by Prof. Gömze. He is author or coauthor of 2 patents, 5 books and more than 250 scientific papers. Recently, he is the chair of the International Organization Board of ic-cmtp ${ }^{3}$ the $3^{\text {rd }}$ International Conference on Competitive Materials and Technological Processes (2014) and ic-rmm ${ }^{2}$ the $2^{\text {nd }}$ International Conference on Rheology and Modeling of Materials (2015).

crystallite size was calculated from the broadening of the reflex to small angles. The values of micro distortions crystal lattice were calculated from the broadening of the reflex to the far corners of the diffraction pattern.

Analysis of the morphology of the pore structure was carried out by scanning electron microscopy by QUANTA 200 3D microscope. The pore size was determined by random secants, the number of measurements was at least 300 .

\section{Results and discussion}

Research was conducted on the polished surface of the ceramic samples sintered at $1650^{\circ} \mathrm{C}$ and holding 1:00 hour (Fig. 1). It was found that the pore structure of the commercial alumina sample is a system of continuous long channelization and disordered forms of dense portions corresponding to the alumina agglomerates, in which at higher magnification there can be seen varying forms of closed pores larger than 5 microns. In fact, this structure corresponds to two interpenetrating components: substance and pore.

In contrast to the ceramics consisting of industrial alumina, the pore structure of the plasma-chemical sample $\mathrm{Al}_{2} \mathrm{O}_{3}$ powder represented as mainly isolated pores with a random pore shape and distinct clusters of various sizes (Fig. 2). Mostly, the amount of isolated pores had a size of less than 2 microns. The average pore size of the clusters was 10 microns.

In the studied ceramics, bimodal distribution of pore size is observed. The first maximum (d1) is due to pores in size less 
than 5 microns, the size of which is commensurate with the size of grains. A second maximum (d2) forms macropores ranging in size from 5 to 100 microns. Such large voids in ceramics are due to the formation of lasting frameworks made of used agglomerates powders during pressing, the dimensions of which determine the size of macropores between them. In coarse fraction ceramic powder, the ratio of pore size of 0.5 microns is substantially lower than the ceramic powders of the nanocrystalline plasmochemical $\mathrm{Al}_{2} \mathrm{O}_{3}$.

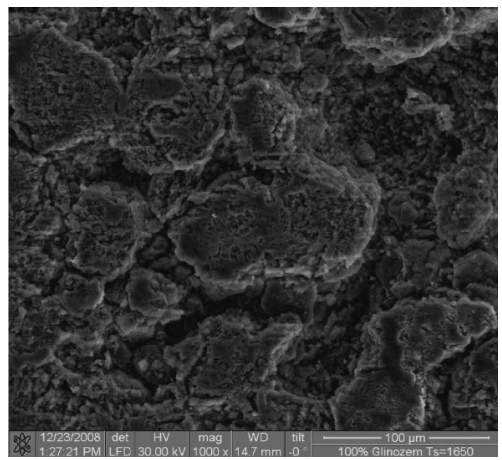

(a)

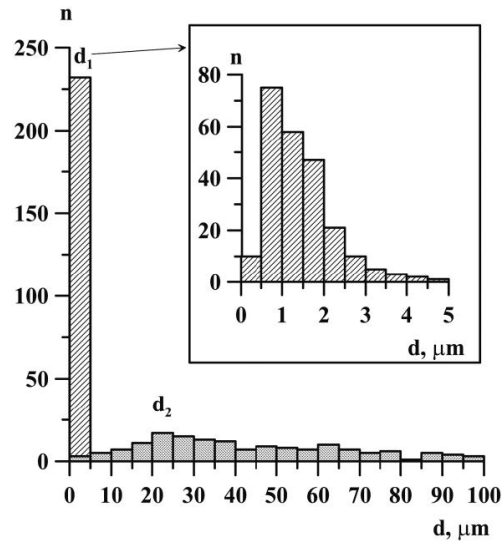

(b)

Fig. 1. The microstructure (A) and pore size distribution (B) for industrial ceramics based on alumina, sintered at $1650^{\circ} \mathrm{C}$ and holding for 1 hour.

1. ábra $\mathrm{Az} 1650^{\circ} \mathrm{C}$-on 1 órán át szinterezett alumínium-oxid alapú ipari kerámiák mikroszerkezete $(A)$ és pórusméret-eloszlása $(B)$

With the increase of the content of plasma chemical powder in the starting mixture the communicating pore space starts to decrease, and thus, the reduction in the size of channelization is considerable. This is evidenced by reduction of the average pore size from 53 to 9 microns for maximum d2. However, in ceramics that contains only plasmochemical powder, the porosity is again increasing. In ceramics containing $90 \%$ plasma chemical powder, the densest structure occurs, and there are isolated pores with random shapes and pores separate clusters. Apparently, this is due to the fact that the alumina $10 \%$ additive added to the plasma chemical $\mathrm{Al}_{2} \mathrm{O}_{3}$ powder destroys the foam-like agglomerates plasma chemical powder on the pressing stage, wherein the particles and agglomerates of industrial alumina are not enough to form a lasting framework on their base.

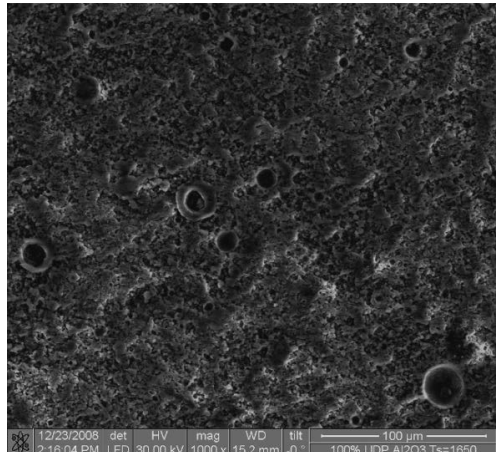

(a)

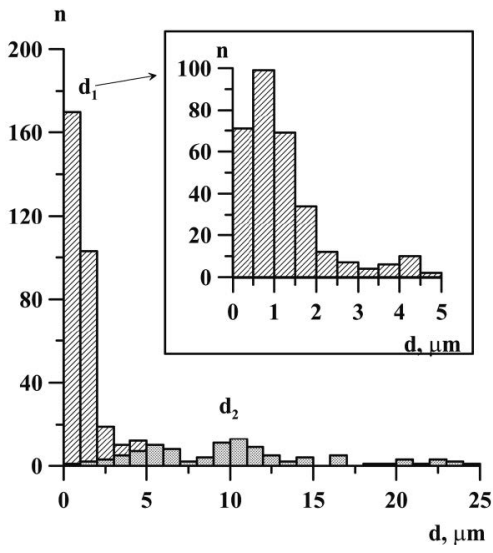

(b)

Fig. 2. Microstructure (A) and pore size distribution (B) for plasma-chemical based ceramic powder $\mathrm{Al}, \mathrm{O}$, sintered at $1650^{\circ} \mathrm{C}$ and holding for 1 hour.

2. ábra A plazma-kémiai eljárással elöállított porból készített és $1650^{\circ} \mathrm{C}$-on 1 órán át szinterezett $\mathrm{Al}_{2} \mathrm{O}_{3}$ kerámia próbatestek mikroszerkezete $(A)$ és pórusméreteloszlása (B)

Research on the influence of the crystallite size on micro distortions crystal lattice showed that the latter decreases with the increase of crystallite D (Fig. 3). Built dependence is described by the following formula:

$$
\left.<\varepsilon^{2}\right\rangle^{1 / 2}=3.4 \cdot \mathrm{D}^{-0.6}
$$

The case when $\left\langle\varepsilon^{2}\right\rangle^{1 / 2} \sim \mathrm{D}^{-1}$ proves that the main contribution to micro distortions lattice in the studied ceramics is made by the interfaces, which are always present in such systems. In this regard, the smaller are the crystallites, i.e. the length of the border, the higher is the level of micro distortions.

The relationship was investigated between the fine crystal structure parameters and the sintering temperature, which indicates that, with an increase in the sintering temperature, the average crystallite size increases linearly, and the level of the crystal microstrains lattice decreases.

An estimation was made for the diffusion activation energy, which is equal to $97 \cdot 103 \mathrm{~J} / \mathrm{mol}$ or $23 \mathrm{kcal} / \mathrm{mol}$, which is 5 times less than the activation energy of self-diffusion of aluminum and oxygen in polycrystalline oxide, from which we may suggest that the main mechanism of mass transfer during sintering is grain boundary diffusion.

We found that the increase in porosity is accompanied with a decrease in crystallite size and microstrain growth. Dependence of crystal lattice micro distortions porosity in alumina ceramics has a pronounced kink in the porosity of about $50 \%$ (Fig. 4). 


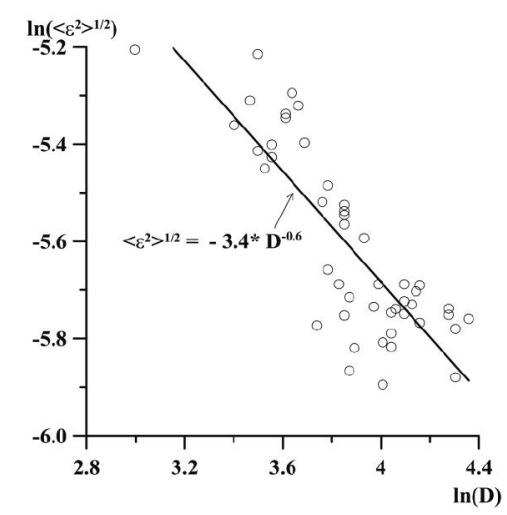

Fig. 3. Dependence of the average level of micron-sized crystallites in alumina ceramics made from powders with different particles.

3. ábra Az alumínium-oxid kerámiákban szinterezéskor kialakuló kristály-méretek függése a gyártáshoz használt porok szemcseméretétől.

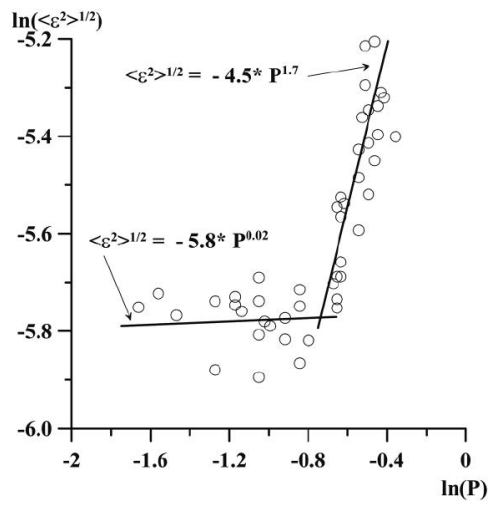

Fig. 4. Micro distortions crystal lattice dependence on the porosity in the studied ceramics.

4. ábra A vizsgált kerámiákban a kristályrács mikro-torzulásainak függése a porozitástól

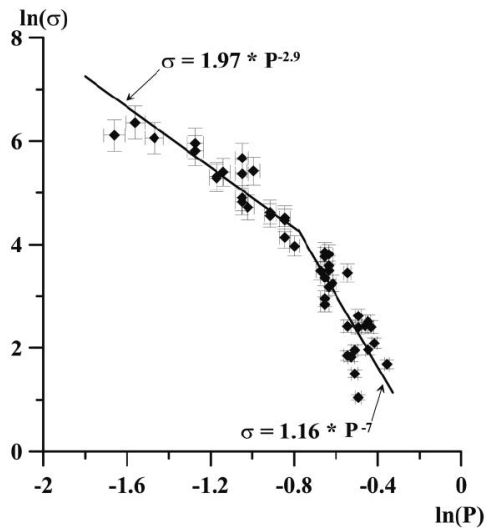

Fig. 5. The compressive strength dependence on the porosity of the ceramic-based powders with different particle sizes.

5. ábra A különböző szemcseméretü porokból készitett készült kerámia próbatestek nyomószilárdságának függése az átlagos pórusátmérőtool

Investigation of the effect of porosity on the strength of the ceramic showed that the strength of the samples decreases significantly with increasing porosity, when porosity is in the range of about $50 \%$, the angle of inclination of the approximating line is changed (Fig. 5). Primarily, it is due to the fact that there is a change in the nature from the isolated pores structure and pore clusters of various shapes and sizes for a ceramics structure consisting of two interpenetrating component, i.e. substance and pore.
Thus, the changing of the pore structure nature is accompanied with a sharp decrease in the strength and growth of the crystal lattice microstrain, which corresponds to the percolation transition in the ceramics under examination.

Type pore volume and pore size also significantly affect the strength of the material. It was found that the tensile strength is greater, the smaller the average pore size and dispersion, and the extrapolation of this dependence to zero porosity showed that the strength of the studied ceramics will be about $3.5 \mathrm{GPa}$, which corresponds to the estimated strength of alumina that is available in the literature $[14,15]$.

\section{Conclusions}

It was found that in the ceramic-based powders with different particle pore structures, the change in the nature of the ceramic frame and the large pore space to isolated pores and pore clusters coincides with the increase of the nanocrystalline powder in the initial mixture of powders.

Pore structure type changes with a porosity of about $50 \%$ and is accompanied with a sharp decrease in strength and a decrease in microstrain, which corresponds to the percolation transition in the ceramics under examination.

Pore size distribution is bimodal. The first maximum is due to pore size of less than 5 microns, the second is a pore size of 5 to 100 microns.

The estimation of the activation energy of the grain growth process during sintering is $23 \mathrm{kcal} / \mathrm{mol}$. This value is showing that the main mechanism of sintering is grain-boundary diffusion.

The determined relationship between crystallite size and crystal lattice micro distortions indicates that the examined ceramics' main defect part is located at the grain boundaries.

Thus, the obtained results enable a directional adjusting of the structure and properties of ceramic materials based on aluminium oxide powders with different particle sizes. This makes possible to practically obtain a variety of structures either as highly porous and substantially zero porosity with a set complex of physical and mechanical properties.

\section{Acknowledgement}

Part of this work is financially supported by Tomsk State University Competitiveness Improvement Program and Siberian Branch Program \#III.23.2.3.

\section{References}

[1] Kulkov, S. N. - Grigoriev, M. V.: Sintering of $\mathrm{Al}_{2} \mathrm{O}_{3}$ ceramics based on different sizes powders, (2010), Építőanyag, Vol. 61. No, 3, pp. 34-38; http://dx.doi.org/10.14382/epitoanyag-jsbcm.2010.3

[2] Kamitani, Kazutaka - Hyodo, Takeo - Shimizu, Yasuhiro - Egashira, Makoto: Fabrication of Highly Porous Alumina-Based Ceramics with Connected Spaces by Employing PMMA Microspheres as a Template; (2009) Advances in Materials Science and Engineering, http://dx.doi.org/10.1155/2009/601850

[3] Okada, Kiyoshi et al: Porous ceramics mimicking nature - preparation and properties of microstructures with unidirectionally oriented pores; (2011) Sci. Technol. of Adv. Mater., Vol. 12, http://dx.doi.org/10.1088/1468-6996/12/6/064701

[4] Isobe, T. - Kameshima, Y. - Nakajima, A. - Okada K., K. - Hotta, Y.: Preparation and properties of porous alumina ceramics with oriented cylindrical pores produced by an extrusion method; (2006) J. Eur. Ceram. Soc., Vol. 26, No. 6, pp. 857-960 
[5] T. Isobe, - Y. Kameshima Y, - A. Nakajima, - K. Okada - Y. Hotta: Gas permeability and mechanical properties of porous alumina ceramics with unidirectionally aligned pores; (2007) J. Eur. Ceram. Soc.,Vol. 27. No. 1, pp. 53-59

[6] Buyakova, S. P. - Kulkov, S. N.: Formation of the structure of porous ceramics sintered from nanocrystalline powders; (2005) Refractories and technical ceramics № 11, pp. 6-11

[7] Gömze, László A. - Gömze, Ludmila N.: Alumina based hetero-modulus ceramic composites with extreme dynamic strength; (2009) Épitöanyag, Vol. 61, No. 2, pp. 38-42 http://dx.doi.org/10.14382/epitoanyag-jsbcm.2009.7

[8] Chen, X. - Chadwick, T. C. - Wilson, R. M. - Hill, R. - Cattell, M. J.: Crystallization of High-strength Fine-sized Leucite Glass-ceramics, (2010) Journal of Dental Research, Vol. 89. pp: 1510-1516

[9] Tomilina, E. - Pronin, O. - Lukin, E. - Kagramanov, G. : Porous ceramics based on alumina; (2000) Glass and ceramics, No. 6, pp. 23-24

[10] Salihov, T. - Kahn, V. - Urazaeva, E. at all: Alumina ceramics filter on phosphate bonds; (2008) Glass and ceramics, No. 8, pp. 28-31

[11] Krasniy, B. at all: Properties of porous permeable ceramic powders based on mono-fractioned corundum and nano-disperse binder; (2009) Glass and ceramics, No. 6. pp. 18-21

[12] Miranda-Hernandez, J. G. - De La Torre, S. Diaz - Rocha-Rangel, E. Synthesis, microstructural analysis and mechanical properties of aluminamatrix cermets; (2010) Épitőanyag Vol. 62/1, pp. 2-5; http://dx.doi.org/10.14382/epitoanyag-jsbcm.2010.1

[13] Kaygorodov, A. - Khrustov, V. : The influence of $\mathrm{Al}_{2} \mathrm{O}_{3}+\mathrm{Al}$ powders stirring time on the quality of alumina based ceramics (2010) Epitöanyag, Vol. 62, No. 4, pp. 102-106;

http://dx.doi.org/10.14382/epitoanyag-jsbcm.2010.21

[14] Andrievskii, R. - Spivak, I.: Strength of refractory compounds and materials based on them; (1989) Chelyabinsk Metallurgy, pp. 250-251
[15] Zhou, Li-Zhong - Wang, Chang-An - Liu, Wei-Yuan: Fabrication of Low Density High Strength Porous Mullite Ceramics by Tert-butyl Alcoholbased Gelcasting Process, (2009) Journal of Inorganic Materials, No. 01 http://dx.doi.org/10.3724/SP.J.1077.2009.01173

$\underline{\text { Ref.: }}$

Grigoriev, M. - Gömze, L. A. - Kulkov, S. N.: Restructuring of Ceramics Features with Changes in the Large and Nanocrystalline Ceramic System Ratio

Építőanyag - Journal of Silicate Based and Composite Materials, Vol. 66, No. 2 (2014), 48-51. p.

http://dx.doi.org/10.14382/epitoanyag-jsbcm.2014.10

\section{Szerkezet-átalakulások és viselkedésbeli változások} a nagy- és nanokristályos kerámia rendszerekben

A szerzốk az alumínium-hidroxid termikus bomlásával és a plazmaszórásos pirolízis módszerével elôállított porokból készített alumínium-oxid kerámiák mikroszerkezetét és tulajdonságait vizsgálták. Az eredmények azt mutatják, hogy a $60 \%$ plazma kémiai úton elóálított $\mathrm{Al}_{2} \mathrm{O}_{3}$ port tartalmazó keverékbôl készült kerámiák mechanikai szilárdsága ugrásszerūen megnô, míg a szinterezéskor kialakuló pórusok mérete jelentôsen lecsökken. Azzal, hogy a pórusátmérốk csökkenésével arányosan nố az aluminium-oxid kerámiák mechanikai szilárdsága, lehetôség nyílik az elméleti mechanikai szilárdság elérésére - illetve megközelítésére. A szerzốk feltárták a krisztallitok mikroszilárdsága és a szinterelt kerámiák makroszilárdsága közötti korrelációt.

Kulcsszavak: alumínium-oxid, feszültség, kerámia porok, mikroszerkezet, nanokristály, pirolízis plazmaszórás, szilárdság

\section{The Perlite Institute}

The Perlite Institute was founded in 1949, a year in which it is estimated only 80,000 tons of perlite ore was mined throughout the world. The unusual properties and advantages of this virtually new material had been known for some time, yet recognition and acceptance was impeded due to a lack of reliable technical data, uniform commercial standards and sufficient public information.

What was needed was a coordinated effort, a continuing campaign to secure the future of the perlite industry - an industry of highly promising but largely unexploited potential. Miners of perlite ore and perlite expanders combined efforts and resources in order to help themselves individually. The Perlite Institute was founded.

Its most important task was to develop, through approved investigation and research, a greater technical and engineering knowledge of perlite and then to disseminate the information to its members, architects, engineers, landscapers and other users of the product.

The Institute's goal was to increase the public's awareness and knowledge of perlite through well-organized and effective programs of publicity and advertising. It would provide a forum for discussing common problems and creating solutions through cooperative thinking and effort. It would assist the perlite producer in marketing, sales promotion and sales training.

\section{Perlite in Gonstruction}

Perlite is a versatile and sustainable mineral that is mined and processed with a negligible impact on the environment. And the green community recognizes perlite-enhanced products - like lightweight insulating concrete roof decks -as a high-performance solutions drawn from a natural material of nearly unlimited supply throughout the world. Research suggests that more than 50 percent of expanded perlite worldwide is used by the construction industry. Perlite plays an important role in a wide variety of construction-related uses including: as an aggregate in lightweight insulating concrete and plaster; as a loose fill insulation material for concrete masonry blocks, cavity walls, in residential homes; and in a variety of specialty applications including fireproofing sprays, chimney fills, interstitial floors, acoustical sprays, etc.

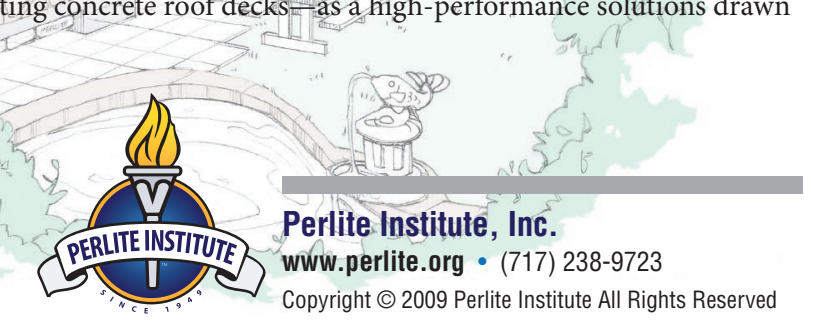

